\title{
Toward Breeding for Resistance to Fusarium Tuber Rot in Caladium: Inoculation Technique and Sources of Resistance
}

\author{
Fahrettin Goktepe, Teresa Seijo, Zhanao Deng ${ }^{1}$, Brent K. Harbaugh, \\ and Natalia A. Peres \\ University of Florida, Institute of Food and Agricultural Sciences, GulfCoast \\ Research and Education Center, 14625 C.R. 672, Wimauma, FL 33598
}

\author{
Robert J. McGovern \\ University of Florida, Doctor of Plant Medicine Degree Program, 1453 \\ Fifield Hall, Gainesville, FL 32611
}

Additional index words. Araceae, Caladium $\times$ hortulanum, Fusarium solani, disease resistance, resistance breeding

\begin{abstract}
Fusarium tuber rot, incited by Fusarium solani, is the major cause of losses of tuber quality and quantity in caladium (Caladium $\times$ hortulanum) during storage and production. To develop a reliable inoculation method for evaluating cultivar susceptibility to Fusarium tuber rot and identifying sources of resistance, the effect of temperature on the mycelial growth of $F$. solani in vitro and on tuber rot in vivo was examined. The optimal temperature was then used to study the aggressiveness of $F$. solani isolates. The effect of temperature $\left(13,18,23,28\right.$, and $\left.33^{\circ} \mathrm{C}\right)$ on radial mycelial growth of nine $F$. solani isolates in vitro was determined, and all responded similarly to temperature variables, with optimal growth predicted to be at $30.5^{\circ} \mathrm{C}$. The relationship of these temperatures to disease development was then determined for the most aggressive $F$. solani isolate 05-20 and it was found that disease development in inoculated tubers was greatest at low temperatures $\left(13\right.$ and $\left.18{ }^{\circ} \mathrm{C}\right)$. Cold damage to tubers was observed at $13{ }^{\circ} \mathrm{C}$; therefore, $18{ }^{\circ} \mathrm{C}$ was chosen for all future disease screening. The aggressiveness of nine isolates was tested on two caladium cultivars. Significant differences among isolates were observed for the diameter of rotted tissue in both cultivars, indicating that choice of isolate was important for screening. Isolates 05-20 and 05-257 were highly aggressive on both cultivars. Tubers of 17 commercial caladium cultivars were inoculated with three isolates $\left(04-03,05-20\right.$, and 05-527) and incubated at $18^{\circ} \mathrm{C}$. The interaction between isolates and cultivars was highly significant $(P<0.0001)$, indicating that cultivars were not equally susceptible to different pathogenic isolates of $F$. solani. Lesion diameters differed significantly $(P<0.0001)$ among cultivars/isolates and ranged from 9.5 mm ('Rosebud' and 'White Christmas' for isolate 04-03) to $23.9 \mathrm{~mm}$ ('Carolyn Whorton' for isolate 05-20). The cultivars were ranked for susceptibility to tuber rot within each isolate and the normalized total rank for the three isolates was used to place cultivars into four categories: resistant ('Candidum', 'Rosebud', 'White Christmas', 'Florida Sweetheart', and 'Aaron'), moderately resistant ('White Wing' and 'Red Flash'), susceptible ('Candidum Jr.', 'White Queen', 'Red Frill', 'Florida Cardinal', 'Miss Muffet', and 'Postman Joyner'), and highly susceptible ('Fannie Munson', 'Gingerland', 'Frieda Hemple', and 'Carolyn Whorton'). The availability of these sources of host plant resistance, aggressive isolates, and resistance assessment techniques will facilitate the development of new Fusarium-resistant caladium cultivars.
\end{abstract}

\begin{abstract}
Received for publication 20 Dec. 2006. Accepted for publication $28 \mathrm{Feb} .2007$.

This research was supported by the Florida Agricultural Expt. Sta. and grants from the U.S. Department of Agriculture/CSREES/TSTAR-C program, the Florida Caladium Growers Association, and the Fred C. Gloeckner Foundation, Inc. We thank Joyce Jones, Richard O. Kelly, Nancy West, and Gail Bowman for their excellent technical support and Mr. D. Bates and Dr. R. Hartman for generous donation of caladium tubers and plants.

${ }^{1}$ To whom reprint requests should be addressed; e-mail zdeng@ufl.edu
\end{abstract}

Caladiums (Caladium $\times$ hortulanum Birdsey) are ornamental aroids valued for their bright, colorful leaves. They are widely used in landscapes, especially in the southern United States, and in production of pot plants worldwide (Evans et al., 1992). The production of tubers is primarily through propagating pieces of cut "seed" tubers (Wilfret, 1993). Thus, tuber quality is critical for field production of tubers as well as for whole tubers used for landscaping or for production of potted plants in the greenhouse (Harbaugh and Tjia, 1985; Overman and Harbaugh, 1982).
Fusarium tuber rot, incited by $F$. solani (Mart.) Saa., is the most important disease that affects caladium tuber quality and quantity (Knauss, 1975; McGovern, 2004). During the past decade, this disease has caused a steady decline in tuber yield of many cultivars in Florida, which supplies more than $95 \%$ of the worldwide demand, and has led in part to elimination of a number of important commercial cultivars (McGovern, 2004). Fusarium infection of tubers has been widespread in commercial cultivars, with disease incidence of up to $90 \%$ to $100 \%$ (Gilreath et al., 1999; McGovern, 2004). The disease cycle and epidemiology of Fusarium tuber rot have not been clearly elucidated, but it appears that the primary mode of fungal survival and spread is on or in "seed" tubers (McGovern, 2004). Chemical control of this fungal pathogen using fungicides has had very limited success (McGovern, 2004). Shoot-tip culture has been used to eliminate Fusarium from "seed" tubers, resulting in an increase in tuber yield and quality and plant performance, but these beneficial effects may be lost within several years because of natural reinfection after the tissue culture-derived seed pieces are planted in the field (Overman and Harbaugh, 1982). Identification, utilization, and improvement of host resistance to Fusarium tuber rot have become priority objectives in caladium breeding (Deng et al., 2005).

Two techniques had been previously described for artificial inoculation of caladium tubers with $F$. solani (Knauss, 1975). One involved spraying a spore suspension onto cut surfaces of tubers and the other consisted of injecting a spore suspension into a small hole cut in the tuber. Disease severity was evaluated as either percent of rotted tuber tissue or plant mortality and reduction in tuber production 3 months later. Although these techniques allowed for identification of this pathogen and assessment of several fungicide treatments for tuber rot control, they did not meet the criteria of speed and reliability needed to determine the level of resistance of breeding parents or new selections in breeding programs focusing on disease resistance.

Breeding of disease-resistant cultivars is an important goal for many crop species and it has proved to be an effective component for managing Fusarium-induced diseases in numerous crops (Hartman et al., 1997; McGrath et al., 1987; Rudd et al., 2001). However, until the past three decades, caladium breeding has been done primarily by private breeders focusing on new leaf colors or shapes (Wilfret, 1993). In the 1970s, the University of Florida initiated a breeding program, but its initial focus was on developing vigorous, multibranching cultivars (Miranda and Harbaugh, 2003), rather than breeding for resistance to any specific disease. Thus, to our knowledge, the genetic variation in caladium with respect to resistance to Fusarium tuber rot has not been well defined. Other than anecdotal evidence from growers, the existence of different levels of 
resistance that might be used for breeding against tuber rot disease among caladium cultivars was not documented because of a lack of effective inoculation techniques and disease assessment procedures. These factors, as well as the need for rapid techniques that allow screening of hundreds or thousands of progeny necessary in a breeding program, have also impeded efforts to breed for Fusarium tuber rot resistance.

The main objectives of this study were 1) to determine appropriate temperatures to be used in screening for resistance to Fusarium tuber rot, 2) to assess the effect of isolate aggressiveness when screening for resistance, and 3) to determine whether resistance to Fusarium tuber rot exists in commercial cultivars to enable a caladium breeding program to improve resistance to Fusarium tuber rot.

\section{Materials and Methods}

Production of disease-free tubers. To reduce potential natural infection of $F$. solani in caladium tubers, tissue culture-derived plants donated by a commercial grower were used in this study. These tissue culture plants were initiated from shoot tips excised from field-grown tubers and produced in vitro as described by Hartman (1974). Tissue culture plants were transferred to $10-\mathrm{cm}$ plastic pots containing a soilless substrate composed of $60 \%$ Canadian sphagnum peat, $20 \%$ perlite, and $20 \%$ coarse vermiculite (VerGro Container Mix A; Verlite Co., Tampa, FL) amended with a $13 \mathrm{~N}-5.7 \mathrm{P}-10.8 \mathrm{~K}$ controlledrelease fertilizer (Osmocote 13-13-13 plus minors; The Scotts Company, Marysville, $\mathrm{OH})$ at $5.3 \mathrm{~kg} \cdot \mathrm{m}^{-3}$. The potted plants were grown on metal benches in a greenhouse with $50 \%$ shade $\left(600-800 \mu \mathrm{mol} \cdot \mathrm{m}^{-2} \cdot \mathrm{s}^{-1}\right)$ under the natural photoperiod in Wimauma, FL, and a temperature range of 20 to $35^{\circ} \mathrm{C}$. Irrigation was provided through capillary mats. Preventive fungicide drenches were applied to control fungal diseases (pythium root rot and Fusarium root rot), following manufacturers' recommendations, on a rotation schedule at a 3-week interval: Phyton 27 (Phyton Cooporation, Edina, MN) + PlantShield (BioWorks, Fairport, NY), Medallion (Syngenta Crop Protection, Greensboro, NC) + Subdue MAXX (Syngenta Crop Protection, Greensboro, NC), or Banrot (Scotts-Sierra Crop Protection Company, Marysville, OH). After $\approx 6$ months of plant growth, the soilless mix in the pots was allowed to dry for $\approx 3$ weeks so it could easily be shaken off roots, then plant shoots and roots were cut off, and the tubers were washed, dried, and stored at room temperature $\left(24-26{ }^{\circ} \mathrm{C}\right)$ until used in these tests.

Fusarium solani isolates. Isolates 04-01, 04-02, and 04-03 were collected in 1998 from rotting tubers of unidentified caladium cultivars. Isolates 05-18, 05-19, 05-20, 05-253, $05-255,05-256$, and 05-257 were collected in 2005 from tubers of 'Frieda Hemple', 'Frieda Hemple', 'Frieda Hemple', 'Tom Tomlinson',
'Red Frill', 'Frieda Hemple', and 'Florida Calypso' respectively. All isolates were cultured on Carnation Leaf Agar (CLA) [15 $\mathrm{g} \cdot \mathrm{L}^{-1}$ Bacto Agar supplemented with irradiated carnation leaf pieces (Fusarium Research Center, Pennsylvania State University, University Park, PA) added just before solidification of the agar], unless otherwise noted. Isolates were frozen at $-80{ }^{\circ} \mathrm{C}$ in $20 \%$ glycerol for long-term storage.

Temperature effect on mycelial growth in vitro. The optimal temperature for mycelium growth of nine $F$. solani isolates (04-01, 04$02,04-03,05-19,05-20,05-253,05-255,05-$ 256 , and $05-257$ ) was tested in vitro at 13,18 , 23,28 , or $33^{\circ} \mathrm{C}$. A 4 -mm diameter cork borer was used to cut agar plugs from 2-week-old cultures grown on water agar (15 g Bacto Agar. $\mathrm{L}^{-1}$ water) plates. Each plug was transferred to the center of a new water agar plate and incubated in a plant growth chamber (series 101; Percival Scientific, Boone, IA) for $7 \mathrm{~d}$ at the respective temperatures. The diameter of the mycelial growth was measured in two perpendicular directions and the values were averaged.

The experiment was arranged in a 5 (temperature) $\times 9$ (isolate) factorial arrangement in a randomized block design with three blocks (replications in time) and three subsamples (plates) per replication. Data were subjected to analysis of variance (ANOVA) and regression analyses with PROC GLM using SAS 9.0 (SAS Institute, Cary, NC).

Temperature effect on disease development. The effect of temperature (13, $18,23,28$, or $33^{\circ} \mathrm{C}$ ) on the ability of $F$. solani to cause tuber rot was examined on two caladium breeding lines (8505 and 7537). Isolate $05-20$ was cultured on CLA at $24{ }^{\circ} \mathrm{C}$ for 10 to $14 \mathrm{~d}$ under constant light until the carnation leaf pieces were covered with abundant sporodochia. Caladium tubers were surface sterilized with $30 \%$ bleach for $30 \mathrm{~min}$ and then rinsed three times with sterile water. Tubers were cut in half and placed within egg cartons, one half per egg holder. Tuber halves were punctured to a depth of $5 \mathrm{~mm}$ in the center of the cut surface with a sterile Phillips head screwdriver (4 $\mathrm{mm}$ maximum diameter of the head). Immediately, two pieces of $F$. solani-colonized carnation leaf were inserted into the hole. The egg cartons were then placed inside plastic boxes with four sheets of wet paper towel to maintain the relative humidity $(\mathrm{RH})$ at $\approx 100 \%$. The plastic boxes were sealed with plastic wrap, and then the inoculated tubers were incubated in the dark at $13,18,23,28$, or $33^{\circ} \mathrm{C}$ for 2 weeks to allow Fusarium tuber rot to develop. After 2 weeks, a scalpel was used to remove the top layer of "suberized" tissue transversely (1-2 mm) from the cut surface of the tuber halves, and the diameter (measured in millimeters) of tuber rot emanating from the inoculation site was measured in two perpendicular directions and averaged.

The experiment was designed as a 5 (temperature) $\times 2$ (breeding line) factorial with each treatment replicated three times, with three tuber halves per experimental unit.
The experiment was repeated and data from the two experiments were pooled because variances were equal. Data were subjected to ANOVA and regression analyses with PROC GLM using SAS 9.0.

Aggressiveness of nine isolates on two cultivars. Nine isolates (04-01, 04-02, 04-03, $05-19,05-20,05-253,05-255,05-256$, and 05-257) were evaluated for aggressiveness on two cultivars ('Candidum' and 'Frieda Hemple'). These cultivars were chosen because grower observations indicated that 'Candidum' and 'Frieda Hemple' appeared to be resistant and susceptible to Fusarium tuber rot, respectively. The isolates were cultured on CLA plates at 24 to $28{ }^{\circ} \mathrm{C}$ for 10 to $14 \mathrm{~d}$, and carnation leaf pieces were used to inoculate tuber halves as described earlier. Tuber halves were incubated in plastic containers at $18{ }^{\circ} \mathrm{C}$ in the dark at $\approx 100 \% \mathrm{RH}$ for 2 weeks to allow Fusarium tuber rot to develop. Tuber rot diameter was measured as described earlier.

Inoculated tubers were arranged in a randomized complete-block design (RCBD), with three replications. Each replicate consisted of five tuber halves per isolate-cultivar treatment combination. The experiment was repeated and data from the two experiments were pooled because variances were equal. Data were subjected to ANOVA using the PROC GLM procedures of SAS 9.0.

Evaluation of commercial cultivars to identify sources of resistance to Fusarium tuber rot. Isolates 04-03, 05-20, and 05-257 were selected for use because they were identified as being highly aggressive on caladium tubers, and were cultured on CLA as described earlier.

Seventeen commercial caladiums ('Aaron', 'Candidum', 'Candidum Jr.', 'Carolyn Whorton', 'Fannie Munson', 'Florida Cardinal', 'Florida Sweetheart', 'Frieda Hemple', 'Gingerland', 'Miss Muffet', 'Postman Joyner', 'Red Flash', 'Red Frill', 'Rosebud', 'White Christmas', 'White Queen', and 'White Wing') were chosen for this test. Tubers $(\approx 4-6 \mathrm{~cm}$ in diameter) were surface sterilized with $30 \%$ bleach for $30 \mathrm{~min}$ and then rinsed three times with sterile water. Tubers were placed under an aseptic laminar airflow hood, cut in half, and punctured to a depth of $5 \mathrm{~mm}$ in the center of the cut surface with a sterile Phillips head screwdriver (4 $\mathrm{mm}$ maximum diameter of the head). Immediately, two randomly selected colonized carnation leaf pieces producing sporodochia of $F$. solani were inserted into the created hole. Inoculated tubers were placed in egg cartoons inside plastic boxes, incubated at $18{ }^{\circ} \mathrm{C}$ for 2 weeks, and assessed for severity of tuber rot as described earlier.

The experiment was arranged in an RCBD with four replications. Two tuber halves per replication for each treatment were assigned as the experimental unit. The entire experiment was repeated, and combined data were subjected to ANOVA with PROC GLM using SAS 9.0.

To categorize cultivars into classes based on susceptibility to Fusarium tuber 
rot, cultivars were ranked from 1 to 17 , within each isolate, with the rank of 1 assigned to the cultivar with the smallest lesion. For two-way ties at a given rank, ranks $n$ and $n+1$ were replaced with $\mathrm{n}+0.5$, which was assigned twice, and the next rank was $\mathrm{n}+2$. The total rank sum (TRS) from all three isolates was then transformed to a normalized total rank by dividing the TRS by 51 , the highest possible TRS, and multiplying it by 100 . Cultivars were placed into four categories based on the normalized total rank: resistant (with a normalized rank between $1.0 \%$ and $25.0 \%)$, moderately resistant $(25.0 \%$ to $50.0 \%)$, susceptible $(50.0 \%$ to $75.0 \%)$, or highly susceptible $(75.0 \%$ to $100.0 \%)$.

\section{Results}

Temperature effect on mycelial growth in vitro. The main effect of isolate and the interaction of isolate $\times$ temperature were not significant at $P<0.05$. The main effect of temperature was significant, so the relationship of mycelial growth and temperature was analyzed with combined data for all nine isolates. There was a nonlinear relationship between mycelial growth and temperature, for temperatures ranging from 13 to $33{ }^{\circ} \mathrm{C}$, expressed by the second-order polynomial equation: diameter (millimeters) $=-106.3+$ 11.6 (temperature) - 0.2 (temperature) $)^{2}(P<$ $0.0001, R^{2}=0.92$; Fig. 1$)$. Using this equation, the estimated optimal temperature to produce the greatest mycelial growth was $30.5{ }^{\circ} \mathrm{C}$.

Temperature effects on disease development in vivo. The two experiments

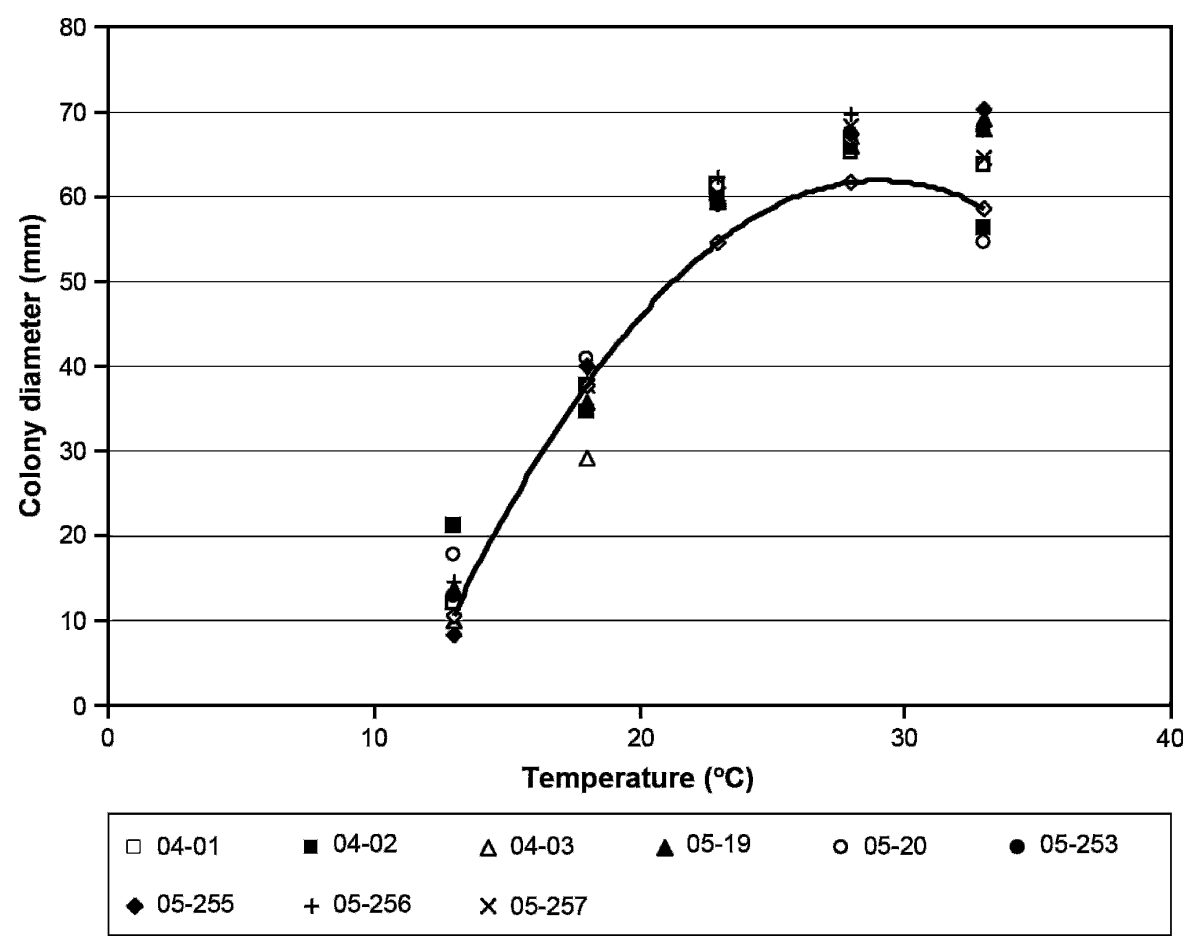

Fig. 1. In vitro growth rate of nine isolates of Fusarium solani at five temperatures $(13,18,23,28$, and $33^{\circ} \mathrm{C}$ ). Based on the second-order polynomial equation [colony diameter (millimeters) $=-106.3+11.6$ (temperature) -0.2 (temperature $\left.)^{2}, P<0.0001, R^{2}=0.92\right]$, the optimum growth rate was estimated to occur at $30.5^{\circ} \mathrm{C}$.

were not significantly different; thus, data were combined during the ANOVA. There was no interaction of breeding line with temperature, indicating that the effect of temperature was similar for both breeding lines. Therefore, the data from the two breeding lines were pooled for regression analyses. There was a quadratic relationship for the effect of temperature on the diameter of rotted tissue area: diameter $=33.95-1.4$ (temperature) +0.0209 (temperature) $)^{2}$, with $R^{2}=0.70$ (Fig. 2).

Although maximum lesion diameter was achieved at $13{ }^{\circ} \mathrm{C}$, changes in tuber tissue texture were observed sometimes when tubers were incubated at $13{ }^{\circ} \mathrm{C}$, probably as a result of cold damage at $13{ }^{\circ} \mathrm{C}$ (Marousky and Raulston, 1973). Therefore, to avoid potential cold damage from exposure to $13{ }^{\circ} \mathrm{C}$, an incubation temperature of $18{ }^{\circ} \mathrm{C}$ was chosen for all subsequent experiments for Fusarium-inoculated tubers.

Aggressiveness of nine isolates on two cultivars. The interaction of isolate with cultivar was significant at $P<0.05$, indicating that relative aggressiveness of the isolates varied with the caladium cultivar inoculated (Table 1). For example, isolate 04-03 was the second most aggressive isolate on 'Frieda Hemple', but was among the least aggressive on 'Candidum'. Two isolates, 05-20 and 05-257, were identified as highly aggressive on both cultivars. Isolate $05-20$ was the most aggressive on 'Frieda Hemple' and 'Candidum', whereas isolate $05-257$ was the most aggressive isolate on 'Candidum' and was the second most aggressive isolate on 'Frieda Hemple'. 


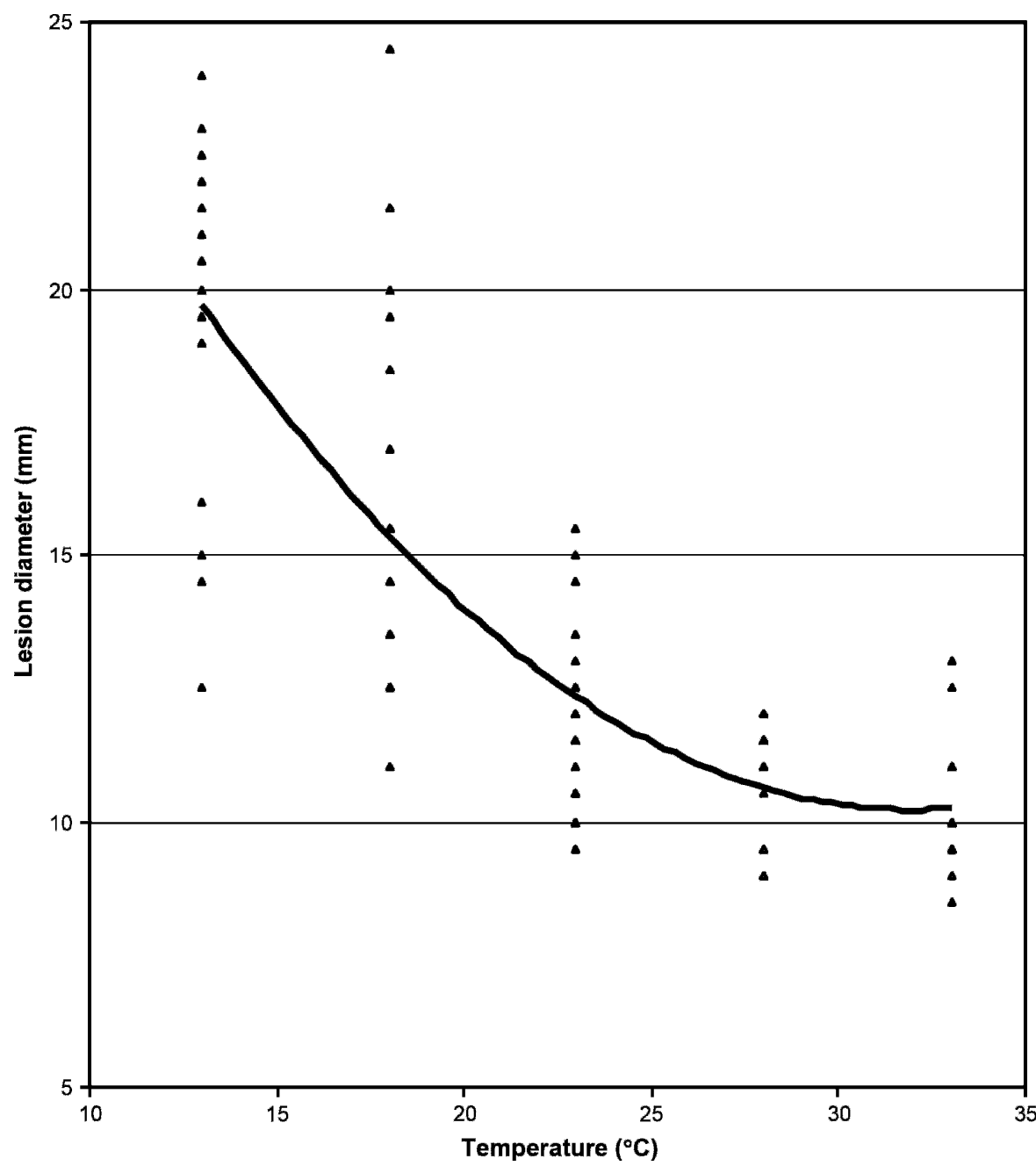

Fig. 2. Lesion diameter (in millimeters) of Fusarium tuber rot after inoculation with Fusarium solani isolate $05-20$ and incubation at five temperatures $\left(13,18,23,28\right.$, and $\left.33{ }^{\circ} \mathrm{C}\right)$ for 2 weeks. Regression analysis indicates a quadratic relationship between incubation temperature and the lesion diameter of rotted tissue area: diameter $=33.95-1.4$ (temperature) +0.0209 (temperature $)^{2}, R^{2}=0.70$.
Table 1. Mean diameter of rotted tuber tissue $7 \mathrm{~d}$ after inoculation of 'Frieda Hemple' (highly susceptible) and 'Candidum' (resistant) caladium tubers with nine Fusarium solani isolates.

\begin{tabular}{lcc}
\hline & \multicolumn{2}{c}{ Cultivar lesion diameter $(\mathrm{mm})$} \\
\cline { 2 - 3 } Isolate & Frieda Hemple & Candidum \\
\hline $04-01$ & 12.6 & 10.0 \\
$04-02$ & 12.5 & 10.3 \\
$04-03$ & 14.9 & 8.3 \\
$05-19$ & 11.3 & 9.2 \\
$05-20$ & 17.7 & 11.4 \\
$05-253$ & 10.2 & 7.8 \\
$05-255$ & 11.2 & 9.9 \\
$05-256$ & 10.3 & 8.7 \\
$05-257$ & 13.5 & 10.4
\end{tabular}

Main effects and interactions for mean diameter

Cultivar $\quad * *$

Isolate

Cultivar $\times$ isolate

**

Least significance difference at $P=0.05$ for cultivar $\times$ isolate means $=1.8$.

*** Very significant at $P=0.01$.

Scherm and Yang, 1996; Wang and Jeffers, 2000 ). The $F$. solani isolates from caladium responded to temperature similarly in vitro, with rapid mycelial growth between 25 and $31{ }^{\circ} \mathrm{C}$ on an artificial medium. However, our results indicated that lower temperatures $\left(13\right.$ or $18{ }^{\circ} \mathrm{C}$ ) favored $F$. solani rot in caladium tubers. Marousky and Raulston (1973) reported that suberin formation on caladium was greatest at $32{ }^{\circ} \mathrm{C}$ and was inhibited at 10 or $15^{\circ} \mathrm{C}$. We observed suberin formation and walling off of the infected area from healthy tissue when inoculated caladium tubers were incubated at 25 to $30{ }^{\circ} \mathrm{C}$. Suberin formation was believed to be one of the major defense responses to pathogen infection in potato tubers (Smith and Smart, 1955; Walker and Wade, 1978). We suspect that caladium tubers incubated at the higher temperatures

Table 2. Lesion diameter (in millimeters) of 17 caladium cultivars inoculated with three isolates of Fusarium solani.

\begin{tabular}{|c|c|c|c|c|c|c|c|c|c|c|}
\hline \multirow[b]{3}{*}{ Cultivar } & \multirow[b]{3}{*}{ Leaf type } & \multicolumn{6}{|c|}{$F$. solani isolates } & \multirow{3}{*}{$\begin{array}{c}\text { Total rank } \\
\text { sum }^{z}\end{array}$} & \multirow{3}{*}{$\begin{array}{l}\text { Normalized } \\
\text { total } \text { rank }^{z}\end{array}$} & \multirow{3}{*}{$\begin{array}{l}\text { Resistance } \\
\text { category }\end{array}$} \\
\hline & & \multicolumn{2}{|c|}{ 04-03 } & \multicolumn{2}{|c|}{$05-20$} & \multicolumn{2}{|c|}{$05-527$} & & & \\
\hline & & Diameter & $\operatorname{Rank}^{\mathrm{z}}$ & Diameter & $\operatorname{Rank}^{z}$ & Diameter & $\operatorname{Rank}^{z}$ & & & \\
\hline Candidum & Fancy white & 9.6 & 4 & 11.3 & 1 & 11.2 & 1 & 6 & 11.8 & $\mathrm{R}$ \\
\hline Rosebud & Fancy pink & 9.4 & 1.5 & 13.9 & 4 & 11.6 & 2 & 7.5 & 14.7 & $\mathrm{R}$ \\
\hline White Christmas & Fancy white & 9.4 & 1.5 & 14.0 & 5 & 11.7 & 3.5 & 10 & 19.6 & $\mathrm{R}$ \\
\hline Florida Sweetheart & Lance pink & 9.5 & 3 & 12.5 & 3 & 11.8 & 5 & 11 & 21.6 & $\mathrm{R}$ \\
\hline Aaron & Fancy white & 10.1 & 7 & 12.1 & 2 & 11.7 & 3.5 & 12.5 & 24.5 & $\mathrm{R}$ \\
\hline White Wing & Lance white & 9.9 & 6 & 15.0 & 7 & 12.4 & 9 & 22 & 43.1 & MR \\
\hline Red Flash & Fancy red & 10.6 & 11 & 14.6 & 6 & 12.0 & 6 & 23 & 45.1 & MR \\
\hline Candidum Jr. & Fancy white & 10.2 & 8 & 15.5 & 9 & 13.9 & 10 & 27 & 52.9 & $\mathrm{~S}$ \\
\hline White Queen & Fancy multicolor & 10.3 & 9.5 & 15.4 & 8 & 14.2 & 11 & 28.5 & 55.9 & $\mathrm{~S}$ \\
\hline Red Frill & Lance red & 9.7 & 5 & 15.8 & 12 & 14.5 & 13 & 30 & 58.8 & $\mathrm{~S}$ \\
\hline Florida Cardinal & Fancy red & 11.3 & 12 & 15.6 & 10.5 & 13.1 & 9 & 31.5 & 61.8 & $\mathrm{~S}$ \\
\hline Miss Muffet & Fancy multicolor & 12.4 & 14 & 16.3 & 14 & 12.3 & 7 & 35 & 68.6 & $\mathrm{~S}$ \\
\hline Postman Joyner & Fancy red & 10.3 & 9.5 & 15.6 & 10.5 & 16.1 & 16 & 36 & 70.6 & $\mathrm{~S}$ \\
\hline Fannie Munson & Fancy pink & 12.8 & 15 & 19.1 & 15 & 14.3 & 12 & 42 & 82.4 & HS \\
\hline Gingerland & Lance multicolor & 13.0 & 16 & 16.2 & 13 & 14.7 & 14 & 43 & 84.3 & HS \\
\hline Frieda Hemple & Fancy red & 11.4 & 13 & 20.3 & 16 & 15.1 & 15 & 44 & 86.3 & HS \\
\hline Carolyn Whorton & Fancy pink & 15.0 & 17 & 23.9 & 17 & 20.4 & 17 & 51 & 100.0 & HS \\
\hline \multicolumn{11}{|c|}{ Main effects and interactions for mean diameter: } \\
\hline Cultivar & $* * \mathrm{x}$ & & & & & & & & & \\
\hline Isolate & $* *$ & & & & & & & & & \\
\hline Cultivar $\times$ isolate & $* *$ & & & & & & & & & \\
\hline
\end{tabular}

${ }^{2}$ Cultivars were ranked from 1 to $17(1$ = least susceptible) within each isolate for relative susceptibility to Fusarium tuber rot. Total rank sum was calculated by adding the ranks for each isolate. The normalized total rank equals the total rank sum divided by 51 (the highest possible rank sum) and multiplied by 100 .

${ }^{y}$ Resistance category was based on the normalized total rank: R, resistant ( $\left.<25.0 \%\right)$; MR, moderately resistant $(25.0 \%$ to $50.0 \%)$; S, susceptible (50.0\% to $\left.75.0 \%\right)$; and HS, highly susceptible $(75.0 \%$ to $100.0 \%)$.

${ }^{\mathrm{x}}$ Very significant at $P=0.01$. Least significance difference at $P=0.05$ for cultivar $\times$ isolate means $=2.1$. 


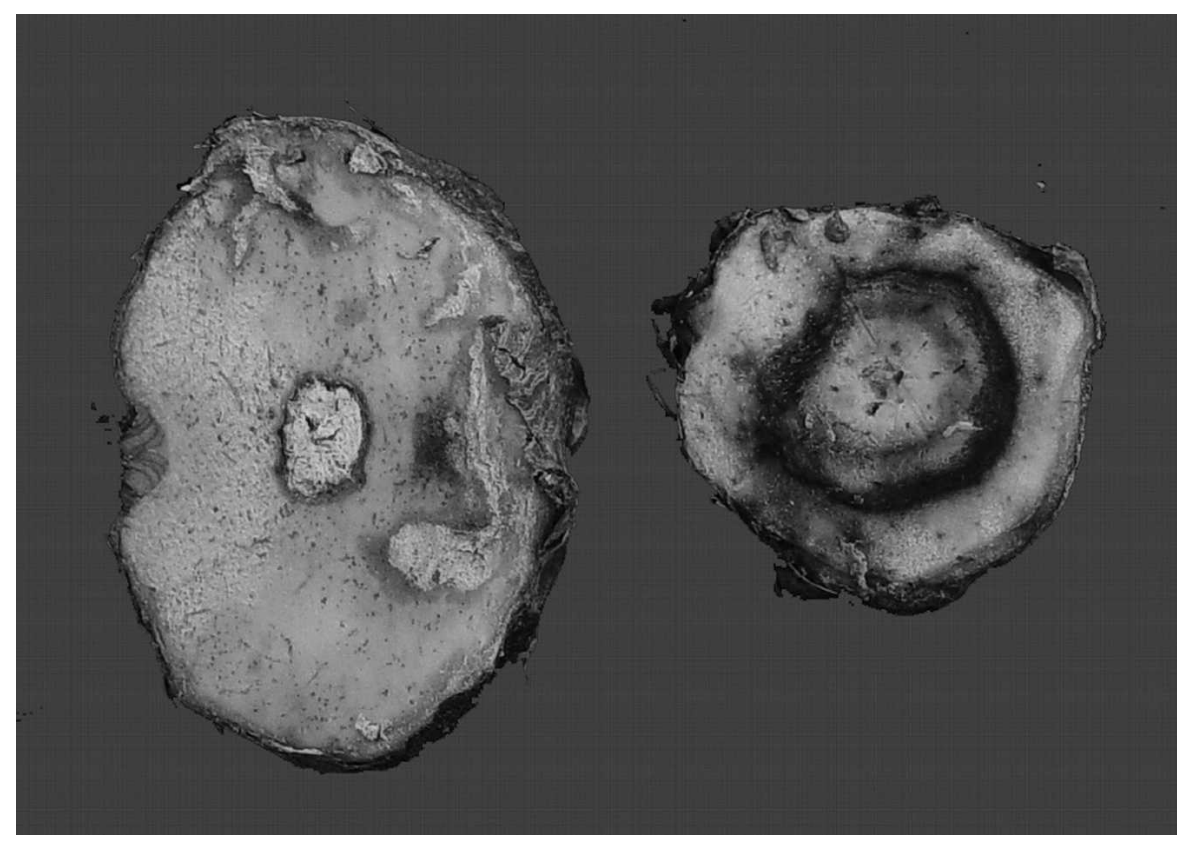

Fig. 3. Fusarium tuber rot in tubers of 'Candidum' (left) a resistant cultivar, and 'Carolyn Whorton' (right) a highly susceptible cultivar. Tubers were cut in half, inoculated at the center of the cut surface with $F$. isolate $05-20$, and incubated at $18^{\circ} \mathrm{C}$ for 2 weeks.

were able to seal off the infected areas and slow down or stop penetration of $F$. solani hyphae, and thus limit rot. On the other hand, low temperatures used in this study suppressed the formation of suberin and walling off of the inoculation wounds in caladium. We also observed that at $13{ }^{\circ} \mathrm{C}$, tubers appeared to show typical signs of cold injury (softening of tissue), complicating evaluation of disease progress. Caladiums are tropical plants and their tubers are sensitive to temperatures less than $15^{\circ} \mathrm{C}$ (Harbaugh and Tjia, 1985). Thus, $18{ }^{\circ} \mathrm{C}$ appeared to be a safe temperature to allow rapid disease (tuber rot) progress while not causing cold injury to tubers.

Selection and use of highly aggressive isolates is another important factor in developing protocols for evaluating Fusarium tuber rot. The aggressiveness of the nine isolates tested varied considerably and was significantly influenced by the caladium cultivar infected. Because a cultivar $\times$ isolate interaction was evident, cultivars should be screened using more than one isolate to ensure broader resistance to $F$. solani, and isolates should be tested on more than one cultivar to ensure that they are highly aggressive across cultivars. Two isolates, 05-20 and 05-257, were highly aggressive on cultivars tested and are good candidates for future screening work.
Our results support grower observations that commercial cultivars differ in their susceptibility to Fusarium tuber rot. For example, growers commonly refer to 'Frieda Hemple' as a troublesome cultivar with respect to tuber rot problems. Using the normalized total rank, we placed 'Frieda Hemple' in the highly susceptible group. Growers rarely have storage problems with 'Candidum' that, in our test, was rated as resistant. These results give us confidence that the assay used can reveal differences in Fusarium tuber rot susceptibility that would be representative of the variation in susceptibility to tuber rot occurring during commercial field production or storage conditions. Furthermore, our results indicate a degree of disease tolerance in commercial cultivars that could be used for breeding new cultivars with resistance to Fusarium tuber rot.

\section{Literature Cited}

Ben-Yephet, Y. and D. Shtienberg. 1994. Effects of solar radiation and temperature on Fusarium wilt in carnation. Phytopathology 84:1416-1421.

Deng, Z., B.K. Harbaugh, R.K. Schoellhorn, and R.C. Andrews. 2005. 2003 Survey of the Florida caladium tuber production industry. Florida Cooperative Extension Services, Institute of Food and Agricultural Sciences, University of Florida. 15 June 2006. <http://edis.ifas.ufl.edu/ EP258>
Evans, M.R., G.J. Wilfret, and B.K. Harbaugh. 1992. Caladiums as potted and landscape plants. Florida Cooperative Extension Services, Institute of Food and Agricultural Sciences, University of Florida. 15 June 2006 $<$ http://edis.ifas.ufl.edu/MG278>

Gilreath, J.P., R. McSorley, and R.J. McGovern. 1999. Soil fumigant and herbicide combinations for soilborne pest control in caladium. Proc. Fla. State Hort. Soc. 112:285-290.

Harbaugh, B.K. and B.O. Tjia. 1985. Commercial forcing of caladiums. Florida Cooperative Extension Service. Circular 621. Univ. Fla. Inst. Food Agr. Sci., Gainesville, FL.

Hartman, R.D. 1974. Dasheen mosaic virus and other phytopathogens eliminated from caladium, taro, and cocoyam by culture of shoot tips. Phytopathology 64:237-240.

Hartman, G.L., Y.H. Huang, R.L. Nelson, and G.R. Noel. 1997. Germplasm evaluation of Gycine for resistance to Fusarium solani the causal organism of sudden death syndrome. Plant Dis. $81: 515-518$

Knauss, J.F. 1975. Description and control of Fusarium tuber rot of caladium. Plant Dis. Rep. 59:975-979.

Marousky, F.J. and J.C. Raulston. 1973. Influence of temperature and duration of curing, storage, shipping and forcing periods on caladium growth. Proc. Fla. State Hort. Soc. 86:363-368.

McGovern, R.J. 2004. Fighting Fusarium. Greenhouse Grower 22:146-150

McGrath, D.J., D. Gillespie, and L. Vawdery. 1987. Inheritance of resistance to Fusarium oxysporum f. sp. lycopersici races 2 and 3 in Lycopersicon pennellii.. Aust. J. Agr. Res. 38:729-733.

Miranda, B.D. and B.K. Harbaugh. 2003. 'Florida Moonlight': A white fancy-leaved caladium for pots and shady landscapes. HortScience 38:635-637.

Overman, A.J. and B.K. Harbaugh. 1982. Effect of tuber source and fumigation on caladium tuber production in two soil management systems. Proc. Fla. State Hort. Soc. 95:175-178.

Rudd, J.C., R.D. Horsley, A.L. McKendry, and E.M. Elias. 2001. Host plant resistance genes for Fusarium head blight sources, mechanisms, and utility in conventional breeding systems. Crop Sci. 41:620-627.

Scherm, H. and X.B. Yang. 1996. Development of sudden death syndrome of soybean in relation to soil temperature and soil water matrix potential. Phytopathology 86:642-649.

Smith, W.L. and H.F. Smart. 1955. Relation of soft rot development to protection barriers in Irish potato slices. Phytopathology 45:649-654.

Walker, R.R. and G.C. Wade. 1978. Resistance of potato tubers (Solanum tuberosum) to Phoma exigua var. exigua and Phoma exigua var. foveata. Aust. J. Bot. 26:239-251.

Wang, B. and S.N. Jeffers. 2000. Fusarium root and crown rot: A disease of container-grown hosta Plant Dis. 84:980-988.

Wilfret, G.J. 1993. Caladium, p. 239-247. In: A. DeHertogh and M. LeNard (eds.). The physiology of flower bulbs. Elsevier, Amsterdam. 